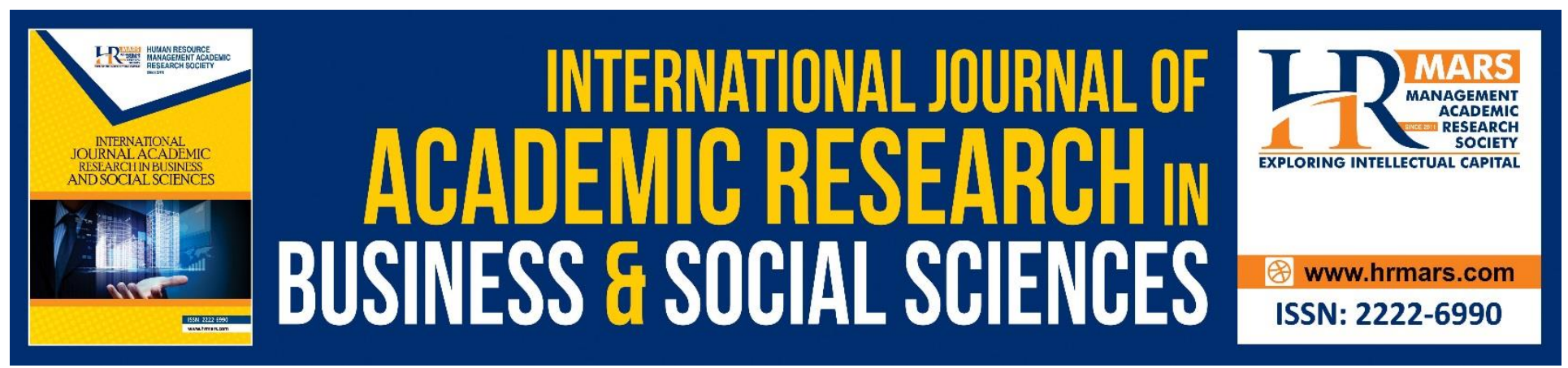

\title{
Intermodal Freight Transport Terminal Planning in Malaysia: Assessing Goods Transportation and Distribution System Performance
}

Mohd Sabri Mohd Arip, Halmi Zainol, Khushairi Rashid, Mohamed Noor Mohid, Abdul Malik A. Tambi

To Link this Article: http://dx.doi.org/10.6007/IJARBSS/v8-i11/5352

DOI: $10.6007 /$ IJARBSS/v8-i11/5352

Received: 07 Nov 2018, Revised: 23 Nov 2018, Accepted: 28 Nov 2018

Published Online: 11 Dec 2018

In-Text Citation: (Arip, Zainol, Rashid, Mohid, \& Tambi, 2018)

To Cite this Article: Arip, M. S. M., Zainol, H., Rashid, K., Mohid, M. N., \& Tambi, A. M. A. (2018). Intermodal Freight Transport Terminal Planning in Malaysia: Assessing Goods Transportation and Distribution System Performance. International Journal of Academic Research in Business and Social Sciences, 8(11), 1758-1771.

Copyright: (c) 2018 The Author(s)

Published by Human Resource Management Academic Research Society (www.hrmars.com)

This article is published under the Creative Commons Attribution (CC BY 4.0) license. Anyone may reproduce, distribute, translate and create derivative works of this article (for both commercial and non-commercial purposes), subject to full attribution to the original publication and authors. The full terms of this license may be seen

at: http://creativecommons.org/licences/by/4.0/legalcode

Vol. 8, No. 11, 2018, Pg. 1758 - 1771

http://hrmars.com/index.php/pages/detail/IJARBSS

JOURNAL HOMEPAGE

Full Terms \& Conditions of access and use can be found at http://hrmars.com/index.php/pages/detail/publication-ethics 


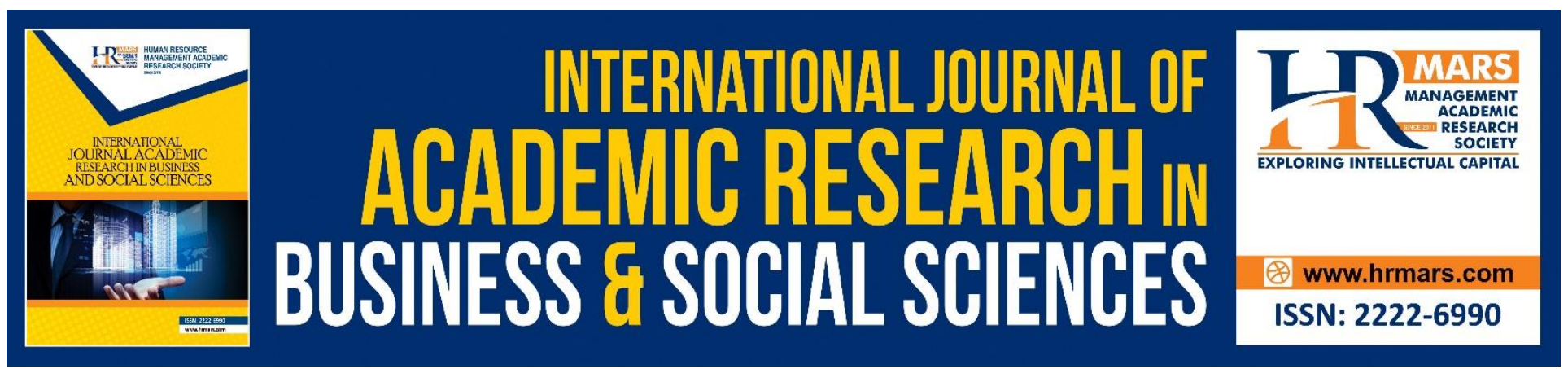

\title{
Intermodal Freight Transport Terminal Planning in Malaysia: Assessing Goods Transportation and Distribution System Performance
}

\author{
Mohd Sabri Mohd Arip ${ }^{1}$, Halmi Zainol², Khushairi Rashid³ ${ }^{3}$ Mohamed \\ Noor Mohid ${ }^{4}$, Abdul Malik A. Tambi ${ }^{5}$ \\ 1,2,3,4 Department of Town and Regional Planning, Faculty of Architecture, Planning and Surveying, \\ Universiti Teknologi MARA, Perak Branch, Seri Iskandar, 32610, Perak, Malaysia \\ ${ }^{5}$ Faculty of Economic and Management Science, Universiti Sultan Zainal Abidin, Gong Badak \\ Campus, Gong Badak, 21300 Kuala Nerus, Terengganu, Malaysia
}

\begin{abstract}
Malaysia still lacks in having a comprehensive development of intermodal freight transport terminal in order to help facilitate transportation and goods distribution system effectively. Therefore, there is a need to consider the establishment of a comprehensive intermodal freight transport terminal planning at these freight terminals; ports, inland ports and distriparks to support the tremendous pace of logistics development and overcome freight transportation and logistics problems in Malaysia. This study focuses on the physical elements, core-on site service elements and core-on site activity elements as the framework to enhance goods transportation and distribution system performance as well as reducing logistical issues and problems for these freight terminals in Malaysia. By using quantitative approaches, a survey was conducted by the researcher towards 257 freight forwarder companies in Malaysia for completing this study. The data were analysed using multiple regression analysis in order to measure the performance of the intermodal freight transport terminals studied. Findings showed that the physical elements, core-on site activities and core-on site services affected goods transportation and distribution system performance of the intermodal freight transport terminal in Malaysia by following the significant aspect.
\end{abstract}

Keywords: Intermodal, Freight, Transportation, Terminal, Planning

\section{Introduction}

A comprehensive freight terminal plays an important role in reducing problems regarding to goods transportation (Federation of Malaysia Freight Forwarder, 2011; Europlatforms, 2004; Galloni, 1999). Freight transport contributes about $20 \%$ of the total traffic within urban areas, but represents $40 \%$ of the pollution (Malhene and Breuil, 2010). The emphasis of a good freight terminal planning is 
necessary and accordance with the enhancement of logistic industries as a key driver for the economic development in this country. (OPP3, 2001-2010; Ministry of International Trade and Industry, 2006; Malaysia's Third Industrial Master Plan, 2006-2020). In an effort to ensure that the logistics sector continues to contribute to the improvement of the economy, facilities such as intermodal freight transport terminal is very essential (IMP3, 2006-2020) to reduce problems such as congestion, vehicle kilometer travelled, high transportation costs, journey time (Jeevan et al., 2015; Arip et al., 2012a; Arip et al., 2012b; Taniguchi et al., 1999; Europlatforms, 2004; Jagminas and Sakalys, 2005; Ballis and Mavrotas, 2007), congestion at ports by goods vehicle (Jamaluddin, 2003; Penang Port Comission, 2011), accident involved goods vehicle (Ministry of Transport, 2010, MIROS, 2011), and issues related to pollution by goods vehicle (Department of Environment, 2010).

In Malaysia, studies of intermodal freight transport terminal have been conducted by various institutions particularly Malaysian Logistics Council, Ministry of International Trade and Industry and institutions of higher learning. The main purpose of the intermodal freight transport terminal is to overcome logistics problems such as congestion, long travel distance for goods transport vehicles, transportation cost, journey time, accident involved goods vehicles and issues related the contamination of goods vehicles. Moreover, the country still lacks in having a comprehensive development of intermodal freight transport terminal in order to help facilitate transportation and goods distribution system (FMFF, 2011). The persistent growth of freight traffic congestion and air pollution in urban areas as well as the increases of imbalance and inefficiency of land use development has driven logistic players and users to find alternative logistic solutions to ease these freight transport problems. In line with the purpose of study, this study trying to assess the physical elements, core-on site service elements and core-on site activity elements framework to measure goods transportation and distribution system performance by these terminals.

Rational of the logistics and intermodal freight transport terminal issues in Malaysia, this paper has formulated the following research questions: 1) To what extent does the quality of intermodal freight transport terminal elements, namely, physical aspects, core-on site services, and core-on site activities freight terminals performance in Malaysia?; 2) Is the performance of intermodal freight transport terminal in Peninsular Malaysia satisfactory?. Through the research questions formed, hopefully this paper could shed a light for the understanding of the goods transportation and distribution system performance and its satisfactory by these terminals in Malaysia. Apart from that, this paper comprises of five sections. Apart from the introduction, the second section reviews the literature on the comprehensive intermodal freight transport terminal development. This section also elaborates the freight terminal concept, elements and its requirements in Malaysia. The third section explains the methodology used in this paper. The fourth part demonstrates the result on the freight terminal performance in Malaysia. This will be done by looking at the comprehensive intermodal freight transport terminal framework that has been outline. The paper concludes in the fifth section by highlighting significant effects from the framework towards the freight terminal planning in Malaysia. 


\section{Literature Review}

This section will discuss the intermodal freight transport terminal planning and its elements to facilitate logistics' distribution and transportation activities. In the first stage, this section will elaborate on the definition of freight terminal, the concept of the terminal, and then related aspects of the characteristics and the framework of the comprehensive intermodal freight transport terminal development.

\section{Definition and Development Concept}

There are a variety of definitions related to intermodal freight transport terminal according to many opinions of other researchers. Referring to Europlatforms (2004), intermodal freight transport terminal is defined as a specific area where all the activities relating to transport, logistics and goods distribution both for national and international are carried out by various operators. Meidute (2005) points out that intermodal freight transport terminal can be defined simply as the concentration points of logistics flows and operations at any scope. In broader terms, a logistics centre can be defined as a centre in a particular area, within which various operators and companies on commercial basis to carry out all activities relating to transport, logistics and distribution. In addition, there are various terminology used to denote intermodal freight transport terminal such as logistics centre, distribution centre, warehouse, transportation terminal, logistics platform, cargo settlement, logistics depot, distripark, and so on (Rimiene and Grundey, 2007). Also, many warehouses and logistics terminals are being referred to logistics centers by their owners. With reference to Jarzemskis (2006), the term logistics center is widely used as a marketing element by many transportation and logistics companies. In Europe, various terms are found such as "Interporto" (Italy), "Plate Forme Logistique" (France), "Logistics Center" (USA, Japan, Singapore and China), "Guterverkehrzentrum" (Germany), "Transportation center" (Denmark) and "Cargo Terminal" (England).

The Intermodal freight transport terminal is not a new concept and has existed since 30 years ago for the facilitation of logistics related activities (Rimiene and Grundey, 2007). In most advanced countries, intermodal freight transport terminal function to facilitate products throughput in which they play a major role in completed products outbound flow and in general supported by a good transportation system infrastructure (David et al., 2002). In this context, intermodal freight transport terminal has also been defined as one of the entities that functions as transfer centers transferring goods from one transportation mode to another (Sirikijpanichkul and Fereira, 2005). To meet the high demands of clients and other interested parties, an efficient method and concept is in need to reduce problems pertaining to logistical activities and the carriage of goods. The development of a more comprehensive intermodal freight transport terminal enables rapid, cheap and punctual delivery of goods.

Taniguchi et al, (2001) states that concepts of intermodal freight transport terminals have been adopted by certain countries worldwide to enhance the system of goods distribution. At these terminals, goods are systematically labelled into categorization before shipping to urban areas. He also asserts that this system reduces the number of trucks needed to transport the goods and the 
makes management of goods easier. Tsamboulas (2005) says that conceptually, the intermodal freight transport terminal is a business venture that includes transportation and storage systems as well as the control of logistics activities. In addition, it acts as a distribution centre, offers services connected to interchange of transportation modes and it is part of the network of other terminal. Aspects such as loading capacity, coordination, final cargo reinforcement, packaging and transshipment and services upgrading are among the activities carried out at an intermodal freight transport terminal for the purposes of facilitating the flow of goods by using information technology and telematics in every activity.

Based on Europlatforms (2004), the conception of an intermodal freight transport terminal should have development and completion with public amenities to ensure fulfilment in operation. Conveniences for workers and conveniences for the use of equipment for its operations ought to be catered for. In encouraging the transfer of goods by way of intermodal transportation, intermodal freight transport terminal needs to have a variety of transportation means including land, sea and air transportations. This combination augurs well in terms of reduction of operational costs, environmental protection and the deployment of a more effective work force (Cooper, 1993). According to Jagminas and Sakalys (2005), the development of intermodal freight transport terminal must be based on the open intermodal transportation centre. The open intermodal centre has been identified as a platform for most small and medium sized transportation modes have access to intermodal transportation support facilities. This enables companies within the intermodal freight transport terminal to rent and pay for the facilities based on level of usage.

\section{The Terminal Framework}

The planning for a good intermodal freight transport terminal should meet the current needs and demands of the logistics sector. It needs to take into consideration the interests of all parties involved in logistics activities for maximum profits as well as to reduce various logistics-related problems. Hence, a clear understanding of the planning of a comprehensive intermodal freight transport terminal is crucial in terms of aspects of elements that felt necessary to be stressed on (Meidute, 2005). Intermodal freight transport terminal makes possible the entry of haulier and forwarder companies, trade organizations, government agencies, financial and insurance companies, and other entrepreneurs closely related to logistical activities (Sulgan, 2006). One of the main differences between the conventional logistics industry and intermodal freight transport terminal is that the latter possesses an environmentally friendly multiple transportation mode network system such as trains, lorries and ships that smoothens the carriage of goods from one area to another (Bentzen and Hoffman, 2004).

Apart from that, intermodal freight transport terminal planning also must act as a commercial centre for various suppliers from a specific area whereby all activities connected to transportation, logistics, distribution of goods for both international and local consumptions can be done in one area. The intermodal freight transport terminal planning should reflect the modern way for the logistics, transportation and goods distribution activities involving activities such as warehousing, distribution centre, storage areas, office, lorry services, banks, postage, insurance services and other 
infrastructure (Europlatforms, 2004). Moreover, planning the inter transportation continuity and networking and the coordination of the modes of transportation is among the main function of an intermodal freight transport terminal (Jarzemskis, 2006). In addition, it is also among the entities that are responsible for storage, transportation and distribution services, thus assisting in the reduction of distance covered especially by lorries carrying goods. Furthermore, a good planning of intermodal freight transport terminal located around big cities can assist in reducing city transportation problems such as traffic congestion, regional competitiveness and enhancing the quality of life among city dwellers towards a better one (Taniguchi et al, 2001; Europlatforms, 2004).

The Planning of a good intermodal freight transport terminal should meet the current needs and demands of the logistics sector. It needs to take into consideration the interests of all parties involved in logistics activities for maximum profits as well as to reduce various logistics-related problems. Hence, a clear understanding of the planning of a comprehensive intermodal freight transport terminal is crucial in terms of aspects of elements that felt necessary to be stressed on. In wider and more general terms, intermodal freight transport terminal is a centre for all companies participating in transportation and logistics activities (Meidute, 2005). In effect, the intermodal freight transport terminal is a complex providing numerous facilities including goods transferable services, warehouse, wholesale market, information centre, exhibition areas, consultation areas and other more effective logistics and goods transfer supporting facilities (Taniguchi et al, 2001).

Referring to Weisbrod et. al., (2002), they point out a framework in designing an intermodal freight transport terminal. The concept of intermodal freight transport terminal that were suggested involved important considerations on the aspects of physical characteristics including size, general location, access, proximity and design. Besides, aspects of core-on site activities are also being considered such as integrated distribution, smart warehousing/specialized warehousing, value added production or processing, intermodal operations and customs operations with foreign trade zone status in designing the comprehensive intermodal freight transport terminal. In addition, the framework has also given consideration to the aspect of core-on site services in planning the intermodal freight transport terminal. Referring to the framework, core on-site services involves the aspects of security and business services such as banking, mail and overnight delivery, public transportation and the aspect of internal transit to ensure the intermodal freight transport terminal designed may fulfil the needs and the demand of logistics industry. This framework is the important factor that needs consideration in planning and designing of intermodal freight transport terminal.

Bentzen and Hoffman (2004) also have stressed on overall structural aspects of the intermodal freight transport terminal elements. In this element, their assumption is that certain aspects are of utmost importance in the comprehensive development of the terminal. The overall development elements they have listed include the following aspects: 
INTERNATIONAL JOURNAL OF ACADEMIC RESEARCH IN BUSINESS AND SOCIAL SCIENCES Vol. 8, No. 11, Nov, 2018, E-ISSN: 2222-6990 @ 2018 HRMARS

Table 1.0: Entire Frame of Intermodal Freight Transport Terminal

\begin{tabular}{|c|c|c|}
\hline \multicolumn{3}{|c|}{ Intermodal Freight Transport Terminal } \\
\hline $\begin{array}{c}\text { Operation and } \\
\text { Maintenance of } \\
\text { Facilities/Building }\end{array}$ & $\begin{array}{r}\mathrm{D} \\
\mathrm{Imp} \\
\mathrm{A}\end{array}$ & $\begin{array}{l}\text { velopment and } \\
\text { mentation of New } \\
\text { ivities/Facilities }\end{array}$ \\
\hline Independent Business Units & Transport Companies & Added Value Services \\
\hline $\begin{array}{l}\text { - } \text { General Cargo Terminal } \\
\text { - } \quad \text { Distribution Centre } \\
\text { - } \quad \text { Containe Hotel } \\
\text { - } \quad \text { Cold Store Terminal } \\
\text { - } \quad \text { Combi Terminal } \\
\text { - } \quad \text { Technical Equipment } \\
\text { - } \quad \text { Service Centre } \\
\text { - Computer and } \\
\text { - } \quad \text { Transport and Research } \\
\text { - } \quad \text { Hazardous Goods Store } \\
\text { - Assembly and Packaging }\end{array}$ & $\begin{array}{ll}\text { - } & \text { Carters } \\
\text { - } & \text { Forwarders } \\
\text { - } & \text { Shipping Firms } \\
\text { - } & \text { Shipbrokers } \\
\text { - } & \text { Stevedores } \\
\text { - } & \text { Haulers } \\
\text { - } & \text { Rail Operators } \\
\text { - } & \text { Ship owners } \\
\text { - } & \text { Air Freight } \\
\text { - } & \text { Terminal Operato }\end{array}$ & $\begin{array}{l}\text { - } \text { Custom } \\
\text { - } \text { Port } \\
\text { - } \text { Port Service } \\
\text { - } \text { Veterinary Authorities } \\
\text { - } \text { Weigh and Measure } \\
\text { - } \text { Inepartment } \\
\text { - } \text { Bank } \\
\text { - Trailer Rental } \\
\text { - Filling Station } \\
\text { - Repair Facilities } \\
\text { - } \text { Welfare Facilities }\end{array}$ \\
\hline
\end{tabular}

Source: Bentzen K. and Hoffmann T. (2004). Service Concept Report for Logistics Centers. European Regional Development Fund, Baltic Sea Region INTERREG III B.

\section{Intermodal Freight Transport Terminal Development in Malaysia}

The development of intermodal freight transport terminal such as port, inland port and distripark in Malaysia involved various agencies, parties, and interested bodies. Malaysia as a developing country tries to strengthen its intermodal freight transport terminal capabilities by the complementation of various development plans such as Malaysia Plans (RMK 10, 2020-2015), IMP3 (2006-2020), National Physical Plan, Regional Plan, Third Outline Perspective Plan (OPP3) and transportation plan to enhance the capabilities and competitiveness of the services provided by these terminals towards the development of logistics industry in Malaysia. The availability of support from governmental bodies and related agencies such as Malaysian Logistics Council, Ministry of Transport and Malaysia International Trade and Industry encouraged the incensement and growth of the logistics industry to strengthen the economy of this country. As reported by IMP3 (2006-2020), an integrated approach to the logistics industry has been developed through the evolution of a 'National Transport Corridor'. This transport corridor provided the basis to remove the pressure on cargo in local ports in Malaysia where there is the requirement for movements of people and freight in a very small area. The 
movements of goods along this national transport corridors strategically linked to the development of freight terminal which offer storage, distribution, cargo consolidation and other specialist services related to the enhancement of the logistics industry for the nation effectively. These intermodal freight transport terminals also equipped with dedicated infrastructure and facilities to attract both domestic and international logistics service providers. The intermodal freight transport terminal; port, inland port and distripark throughout the country being the part of the infrastructure of the logistics industry and placed where there is a higher density of industrial production activities in Malaysia.

In line with the objective to improve trade efficiency and enhance logistics systems, a multimodal transportation network has been developed in Malaysia. About RM2.7 billion being invested to build roads and railways leading to key ports and airports while logistics management will be improved to enhance efficiency of transportation of cargo through rail, ports and airports (RMK-10, 2010-2015). To increase the efficiency of cargo movement, shippers including exporters, importers and freight forwarders will be encouraged to utilize multimodal transportation to reduce the need for long distance road haulage (OPP3, 2001-2010). As reported by IMP3 (2006-2020), the government will continue to enhance multimodal transport modes through rail and inland waterways to relieve the pressure of congestion of haulage traffic and roads. Strategies to be formulated include minimizing the impact of the shift of the business of road haulage companies. This initiative will be private sector driven. Companies will be encouraged to enter into direct operations with rail freight services, in partnership with KTMB, and operate container terminals at rail terminals. In addition, the development of roads will continue to focus on increasing accessibility which will facilitate the establishment of new growth centre as well as reduce travel time and costs. Higher standards will be applied in the construction of new roads especially those that link the industrial areas, ports and airports (OPP3, 2001-2010).

To facilitate greater freight rail movement and relieve congestions on roads, the electrified doubletrack railway project being extended to Johor Bahru to complete the network and increase operational efficiency (RMK-10, 2010-2015). As reported by OPP3 (2001-2010), railway infrastructure development has been focused on capacity expansion and upgrading of the rail network to provide rail transport services as well as the enhancement of safety and maintenance standards. Railway links to the ports, airports, industrial zones and high density corridors to enable greater accessibility and competitive pricing for the production, transportation and distribution of goods. Haulage and passenger capacity will be further increased by the phased double tracking and electrification of the railway network beginning with the Rawang to Ipoh segment. The phased double tracking and electrification of the national railway network is part of the planned Trans-Asian Railway link between Kunming, People's Republic of China and Singapore. This regional rail project will greatly improve cross-border rail links especially for freight transportation.

\section{Research Methodology}

The methodology employed in this study is quantitative in nature. Therefore, a quantitative instrument was the appropriate method to be used to achieve the study objectives. This was 
important to identify the extent of the factors that have significant influence (Creswell, 2014; Sekaran, 1984). A stratified sampling method approach was selected as the method to be used in order to obtain the necessary primary data from 257 freight forwarder companies. This study mainly used questionnaires to gather important information from the respondents. A questionnaire was designed which contained a few main sections to fulfil the study needs and objectives. The questions were designed based on a likert scale format, followed with a few open-ended and close-ended questions. The questionnaires have been grouped into to seven major components' containing the aspects of company profile and goods transportation, freight logistics activities, intermodal freight transport terminal elements at ports, inland ports and distriparks, the ability to reduce goods distribution problems, the advantages for goods transportation and distribution system by using intermodal freight transport terminal in Malaysia, the priority of intermodal freight transport terminal elements and the types of intermodal freight transport terminal elements that should be provided at ports, inland ports and distriparks in Malaysia.

The data analysis techniques to analyse the data involved inferential statistical tests. Statistical inference enabled the researcher to make assumptions about respondents by using multiple regression analysis. This analysis enables the researcher measured two variables, namely dependent variable (intermodal freight transport terminal performance) and independent variables (physical aspects, core-on site activities and core on site services). Basically, this technique was used to test whether factors generated have a significant impact between variables. The multiple regression analysis value that would be appropriate was the guide to accept the significant between independent and dependent variables. The critical value of multiple regression analysis also was the guide to determine the level of mutual relationship between the variables that were studied. Significant level $(\alpha)$ was set at the level of 0.05 . Statistic was used to measure the strength of the relationship between variables where the value approaching 0 indicates a strong relationship and the value above 0.05 shows that there is no significant among the variables.

\section{Analysis and Findings}

egression results shown the three independent variables which were represented by physical element, core-on site activity elements and core-on site service elements toward goods transportation and distribution system performance in Peninsular Malaysia as shown in table 2.0. Table 2.0 also shows a summary of four independent variables output model that go into the regression model $\mathrm{R}(\mathrm{.888})$, where it's a correlation between the three variables and constant independent variables. After all of the correlations and the three variables measured, the $R$ squared was .789. This means there were $78.9 \%$ of the variation in the dependent variable were explained by 3 independent variables and the balance $21.1 \%$ were the other factors does not include into the model. 
INTERNATIONAL JOURNAL OF ACADEMIC RESEARCH IN BUSINESS AND SOCIAL SCIENCES

Vol. 8, No. 11, Nov, 2018, E-ISSN: 2222-6990 @ 2018 HRMARS

Table 2.0: Regression Analysis for Goods Transportation and Distribution System Performance at Intermodal Freight Transport Terminals Malaysia Model Summary

\begin{tabular}{|l|r|}
\hline $\mathbf{R}$ & .888 \\
\hline R Square & .789 \\
\hline Adjusted R Square & .785 \\
\hline Std. Error of the Estimate & .19120 \\
\hline
\end{tabular}

Based on ANOVA table 3.0, the statistic F was 210.844 and it's P-value was $<0.001$ which was less than 0.05 . As a result $78.9 \%$ of the three independent variables will affect the dependent variable.

Table 3.0: Regression Analysis for Goods Transportation and Distribution System Performance at Intermodal Freight Transport Terminals in Malaysia ANOVA Result

\begin{tabular}{|l|r|r|r|r|l|}
\hline \multicolumn{1}{|c|}{ Model } & \multicolumn{1}{c|}{$\begin{array}{c}\text { Sum of } \\
\text { squares }\end{array}$} & \multicolumn{1}{c|}{ Df } & \multicolumn{1}{c|}{$\begin{array}{c}\text { Mean } \\
\text { square }\end{array}$} & \multicolumn{1}{c|}{ F } & \multicolumn{1}{c|}{ Sig } \\
\hline Regression & 23.123 & 3 & 7.708 & 210.844 & $.000(a)$ \\
\hline Residual & 6.178 & 169 & .037 & & \\
\hline Total & 29.301 & 172 & & & \\
\hline
\end{tabular}

Table 4.0 shows three important independent variables which were explained by goods distribution system performance. Based on Beta for the physical element, we can see the value of Beta was .425, that shows a positive value between the physical element and goods distribution system performance and have significant influence at $<0.001$ level. Beta values for core-on site activities was .284, it's also showing a positive value between the core-on site activities and goods distribution system performance with significant influence at $<0.001$ level. Besides, Beta values for core-on site services was .201 which also shows a positive relationship between core-on site services and goods distribution system performance with significant influence at $<0.001$ level.

Table 4.0: Regression Analysis for Goods Transportation and Distribution System Performance at Intermodal Freight Transport Terminals in Malaysia T Test Result

\begin{tabular}{|l|r|r|r|r|r|}
\hline \multirow{2}{*}{ Model } & \multicolumn{2}{|c|}{$\begin{array}{c}\text { Unstandardized } \\
\text { Coefficients }\end{array}$} & \multicolumn{2}{c|}{$\begin{array}{c}\text { Standardized } \\
\text { Coefficients }\end{array}$} & \multirow{2}{*}{ sig } \\
\cline { 2 - 5 } & \multicolumn{1}{|c|}{ B } & $\begin{array}{c}\text { Std. } \\
\text { Error }\end{array}$ & \multicolumn{1}{c|}{ Beta } & t & \\
\hline Constant & .340 & .130 & & 2.607 & .010 \\
\hline Core-on Site Activities & .284 & .067 & .289 & 4.218 & .000 \\
\hline Core-on Site Services & .201 & .055 & .221 & 3.631 & .000 \\
\hline The Physical Elements & .425 & .056 & .451 & 7.615 & .000 \\
\hline
\end{tabular}


These findings showed that the physical elements, core-on site activities and core-on site services affect goods distribution system performance for the intermodal freight transport terminal in Malaysia following the significant aspect. The first aspect was physical aspects (Beta $=.425$ ), second was core-on site activities (Beta $=.284$ ) and the third was the aspect of core-on site services (Beta=.201). This means that the physical aspects are the most important element followed by coreon site activities and core-on site services elements which determined the goods distribution system performance at intermodal freight transport terminals in Malaysia.

\section{Conclusion}

This study seeks to examine the relationship between the independent variables and the dependent variables of freight terminal in Malaysia. From the analysis that has been carried out, there are three elements used and tested. First the researcher tested whether the goods distribution system performance is affected by the physical elements of intermodal freight transport terminal, second the researcher tested whether goods distribution system performance is affected by intermodal freight transport terminal core-on site activities and the third element the researcher tested whether goods distribution logistics system performance is influenced by intermodal freight transport terminal core-on site services element. As a result, this study found out that the intermodal freight transport terminal physical element, core-on site activities and core-on site services influenced goods distribution system performance that referred to correlation analysis which was carried out at intermodal freight transport terminals in Malaysia. Beta for physical elements, core-on site service elements and core-on site activities elements showed a positive relationship between the three elements and goods distribution system performance and it has significant influence. The study also gives a very clear finding that the physical elements, core-on site activities and core-on site services affect goods distribution system performance following sequence. The first is physical elements, second is core-on site activity elements and the third is core-on site service elements. This means that the physical elements are the most important element followed by core-on site activities and core-on site services who will determine the goods distribution system performance at intermodal freight transport terminals in Malaysia.

\section{Acknowledgement}

The author wishes to thank the Malaysia Institute of Transport (MITRANS), Malaysia Logistics Council (MLC) and Ministry of Higher Education (MOHE) for the research grant and financial support.

\section{Corresponding Author}

Mohd Sabri bin Mohd Arip, Department of Town and Regional Planning, Faculty of Architecture, Planning and Surveying, Universiti Teknologi MARA, Perak Branch, Seri Iskandar Campus, 32610 Seri Iskandar, Perak, Malaysia. Email: sabri416@perak.uitm.edu.my

\section{References}

Arip, M. S. M., Mohid, M. N. Bin, Tambi, A. M. A., \& Shukor, I. A. (2012a). A framework of logistics village in reducing the problem regarding goods transportation in peninsular Malaysia. BEIAC 2012 - 2012 IEEE Business, Engineering and Industrial Applications Colloquium, 273-278. 
INTERNATIONAL JOURNAL OF ACADEMIC RESEARCH IN BUSINESS AND SOCIAL SCIENCES

Vol. 8, No. 11, Nov, 2018, E-ISSN: 2222-6990 @ 2018 HRMARS

https://doi.org/10.1109/BEIAC.2012.6226066

Arip, M. S. M., Mohid, M. N. Bin, Tambi, A. M. A., \& Shukor, I. A. (2012b). Goods distribution centre services infrastructures in peninsular Malaysia. BEIAC 2012 - 2012 IEEE Business, Engineering and Industrial Applications Colloquium, 269-272. https://doi.org/10.1109/BEIAC.2012.6226065 Ballis, A. and Mavrotas, G. (2007). Freight Village Design Using The Multicriteria Method PROMETHEE, Operational Research. An International Journal.. Vo17., No.2 (2007), pp. 213-232.

Bentzen K. and Hoffmann T. (2004). Service Concept Report for Logistics Centres. European Regional Development Fund, Baltic Sea Region INTERREG III B. BESTUSF II, 2006. Quantification of Urban Freight Transport Effect I. Project co-funded by the European Commission within the Sixth Framework Programme (2002-2006). Retrieved 2011, June 4 from http://www.spatial.baltic.net/_files/NeLoC_Report.pdf

Cooper J. (1993). Strategy Planning in Logistics and Transportation. Kogan Page Limited, London.

Creswell, J. W. (2014). Research Design: Qualitative, Quantitative and Mixed Methods.

David, J. B., Stephen, L., Joe, B. H. (2002). Logistics. Prentice Hall, New Jersey Dawood, N. and Marasini, R. (2001). Stockyard layout planning and management for the precast concrete products industry. Logistics Information Management vol. 14, No. 5/6, 328-336.

Department of Environment, (2010). Environment Statistics Compedium. Retrieved 2010, July 3 from http://www.doe.gov.my/portal/

Europlatforms, EEIG (2004). Logistics Centres Directions for Use, A report by EUROPLATFORMS EEIG. Retrieved 2011, January 40 from http://www.unece.org/fileadmin/DAM/trans/main/eatl/docs/ENREVWhat_is_a_Freight_Villag eFinalcorretto.pdf

Federation of Malaysia Freight Forwarder (2011). Round Table Discussion. The Planning of Logistics Village - A New Concept of Good Distribution system in Peninsular Malaysia. 11th November 2011 at Malaysia Institute of Transport (MITRANS), Universiti Teknologi MARA, Shah Alam, Selangor Darul Ehsan.

Galloni, G. (1999). FV-2000 - Quality of Freight Villages Structure and Operations //Final Report for Publication. Europlatforms E.E.I.G. 1999. 79 p. Prieiga perinterneta: Retrieved 2011, June 8 from <http://www.freightvillage.com/fv2000/report/FReport.htm >

Jagminas, T. and Sakalys, A. (2005). Logistics center development in Panevezys: Experiences on finding a balance between business activities and environmental aspects.

Jeevan, J., Ghaderi, H., Bandara, Y. M., Saharuddin, A. H., \& Othman, M. R. (2015). The Implications of the Growth of Port Throughput on the Port Capacity: the Case of Malaysian Major Container Seaports. International Journal of E-Navigation and Maritime Economy, 3, 84-98. https://doi.org/10.1016/j.enavi.2015.12.008

Jamaluddin Mahmud (2003). Liberalization of The Container Haulage Industry in Malaysia, Transport and Communications Bulletin for Asia and the Pacific No. 73-98

Jarzemskis A. (2006). Freight Transport in Vilnius and AdRem Terminal. Workshop Vilnius 27-28 September. $\quad$ Retrieved (2011, Mac from http://www.bestufs.net/download/Workshops/BESTUFS_I/Vilnius_Sep07/BEST

UFS_Vilinius_Sep07_Jarzemskis_VilniusTechnicalUniversity.pdf

Malhene N. and Breuil D., (2010). Conceptualization of the evolution process of Urban Freight 
INTERNATIONAL JOURNAL OF ACADEMIC RESEARCH IN BUSINESS AND SOCIAL SCIENCES

Vol. 8, No. 11, Nov, 2018, E-ISSN: 2222-6990 @ 2018 HRMARS

Transport. Proceedings of the 3rd International Conference on Information Systems, Logistics and Supply Chain Creating value through green supply chains ILS 2010 - Casablanca (Morocco), April 14-16.

Meidute I. (2005). Significance of Logistics Centres for Development of IntermodalTransport Services in Lithuania // Proceedings of the 5th International Conference RelStat'05, Riga, 2005. p. 271275.

Ministry of Transport (2010). Significant Contribution by Transport Sector towards Malaysia's Economic Strong Growth in Second Quarter. Retrieved (2013, January 7) fromhttp://www.mot.gov.my/Newsroom/Press\%20Release/Press\%20Statement\%20Min ister\%20of\%20Transport\%20on\%20the\%202nd\%20Qtr\%20BNM\%20Report.pdf

MIROS (2011). Malaysian Institute of Road Safety Research. Retrieved (2011, January 21) http://www.mygeoportal.gov.my/sites/default/files/MIROS.pdf

MITI (2006). Trade and Transport Facilitation: The Malaysian Experience and Milestones, Services Development Division Ministry of International Trade and Industry (MITI) MALAYSIA. Retrieved 2011, January 7 from http://www.unescap.org/tid/projects/egmtf_s3Damiri.pdf

OPP3 (2001-2010). Third Outline Perspective Plan, Economic Planning Unit. Jabatan Perdana Menteri

(Prime Minister Department), Malaysia, (2001-2010). Retrieved 2011, January 21 from Economic planning Unit website:.http://www.epu.gov.my/home\#=e.

Penang Port Comission (2012). Annual Report 2012. (Retrieved 2014, April 27) http://Www.Penangport.Com.My/Pdf/AnnualReports/2012_Annual\%20report.Pdf

Rimiene, K. and Grundey, D. (2007). Logistics Centre Concept through Evolution and Definition, Issn 1392-2785 Engineering Economics (2007). No 4 (54) Commerce Of Engineering Decisions, Kauno technologijos universiteta, Kaunas.

RMK-10 (10th Malaysia Plan) (RMK-10, 2011-2015.) Retrieved (2011, January 4) from Economic Planning Unit website:.http://www.epu.gov.my/home\#=e

Sekaran, U. (1984). Research method for managers: A skill-building approach. New York: John Wiley and Sons.

Sirikijpanichkul, A. and Ferreira, L. (2005). Multi-Objective Evaluation of Intermodal Freight Terminal Location Decisions. Proceedings of the 27th Conference of Australian Institute of Transport Research (CAITR), Queensland University of Technology, 7-9 December 2005.

Sulgan M. (2006). Logistics Park Development in Slovak Republic. Transport-2006, Vol XXI, No 3, 197 200.

Taniguchi E., Noritake M., Yamada T. and Izumitani T. (1999). Optimal Size and Location Planning of Public Logistics Terminals, Transportation Research Part E 35, (207-222).

Taniguchi E., Noritake M., Yamada T. and Izumitani T. (2001). City Logistics. Network Modeling and Intelligent Transport Systems Pergamon, (Amsterdam)

Third Industrial Master Plan (IMP3) 2006 - 2020. Chapter 25: Logistics. Retrieved from Ministry of International Trade and Industry. Retrieved (2011, February 4) from http://www.miti.gov.my/cms/documentstorage/com.tms.cms.document.Document_879bae5 9-c0a81573-1bef1bef 926c5327/chapter14_25.pdf

Tsamboulas, D. (2005). Policies Implementation for developing Freight Villages in Greece. Integration of Cargo Transport Modes \& Nodes in CADSES Area. 
Weisbrod, Roberta. E., Swiger, E., Muller, G., Rugg, M. F., \& Murphy, M. K. (2002). Global freight villages: A solution to the urban freight dilemma. Proceedings from TRB Annual Meeting. Washington, D.C: Retrieved (2010, Mac 6) from http://74.125.95.132/search?q=cache:tURWyssFBK8J:www.uppermidwestfreight.org/resource s/GLOBAL_FREIGHT_VILLAGES.doc+GLOBAL+FREIGHT+VILLAGES\&hl=en\&ct=clnk\&cd=2\&gl=us \&client=firefox-a. 